\title{
PERKAWINAN SIRRI DALAM PERSPEKTIF HUKUM ISLAM DAN UNDANG-UNDANG NOMOR 1 TAHUN 1974 TENTANG PERKAWINAN
}

\author{
Armansyah \\ Sekolah Tinggi Ilmu Syari'ah (STIS) AL-Amin Bima \\ armansyah19.boro@gmail.com
}

\begin{abstract}
:
Status of the unregistered marriages in social life is assumed as the unwritten marriages in Nation. Meanwhile, it is legal in Islamic perspective although it not written in Religion Office based on constitution. The problem effect of Unregistered Marriages based on constitution No 23, 2006 is the kid can not receive their personal identity right, document of born, document of marriages, card of family, card of nationality. In Islamic law, the marriages law is one of the aspect which more applied by most of Muslim in the word compared the muamalah. The marriages is the fundamental aspect or mitsaan galidan assumed legal if the requirements fulfilled based on al-Qur'an and Hadits. Scholars explained the requirements of marriages are candidate of husband, and wife, guardian of marriages, two witnesses, take and give (Ijab and qabul). The constitution No 1, 1947 chapter 2 verse (1) said that Marriages is legal if it done based on the Law of each religion and it trust.
\end{abstract}

Keywords: Unregistered Marriages, Islamic Low, Constitution No 1, 1947.

\section{Pendahuluan}

Dewasa ini di Indonesia, masalah nikah sirri dikalangan masyarakat semakin mencuat. Kerapkali terjadi diberbagai wilayah, yang pada akhirnya dalam pandangan para ulama nikah sirri masih menjadi perdebatan, sehingga sukar untuk menetapkan bahwa nikah sirri itu sah atau tidak. Hal ini dikarenakan masih banyak ulama dan juga sebagian masyarakat yang menganggap bahwa nikah sirri lebih baik dari pada perzinahan. Padahal bila dilihat dari berbagai kasus yang ada, menyatakan nikah sirri tampak lebih banyak menimbulkan kemudharatan dari pada manfaatnya. Padahal secara esensial, perkawinan merupakan suatu ikatan lahir batin antara laki-laki dan perempuan yang terinstitusi dalam satu lembaga yang kokoh, dan diakui baik secara agama maupun secara 
hukum yang bertujuan untuk mewujudkan keluarga yang bahagia dan tentram.

Nikah sirri atau nikah yang dirahasiakan memang sudah dikenal dikalangan para ulama. Hanya saja nikah sirri yang dikenal pada masa dahulu berbeda pengertiannya dengan nikah sirri pada saat ini. Dahulu yang dimaksud dengan nikah sirri yaitu nikah yang sesuai dengan rukunrukun nikah dan syaratnya menurut syari'at, hanya saja saksi diminta tidak memberitahukan terjadinya nikah tersebut kepada khalayak ramai, kepada masyarakat dan dengan sendirinya tidak ada "Walimah alUrsy". ${ }^{1}$ Dalam hukum Islam, hukum perkawinan merupakan salah satu aspek yang paling banyak diterapkan oleh kaum muslimin di seluruh dunia dibanding dengan hukum-hukum muamalah. Perkawinan adalah mitsaqan ghalidan, atau ikatan yang kokoh, yang dianggap sah bila telah memenuhi syarat dan rukun pernikahan. Berdasarkan Alquran dan hadits, para ulama menyimpulkan bahwa hal-hal yang termasuk rukun pernikahan adalah calon suami, calon isteri, wali nikah, dua orang saksi, ijab dan qabul. ${ }^{2}$

Sedangkan dalam Undang-undang Nomor 1 Tahun 1974 tentang perkawinan pasal 1 dikatakan bahwa, perkawinan ialah ikatan lahir batin antara seorang laki-laki dengan seorang perempuan sebagai suami istri dengan tujuan membentuk rumah tangga (keluarga) yang bahagia dan kekal berdasarkan Ketuhanan Yang Maha Esa. Perkawinan menurut Undang-undang ini bukan hanya sebagai suatu kontrak keperdataan biasa, namun juga mempunyai nilai ibadah. Selain itu suatu perkawinan sangat erat sekali hubungannya dengan Agama yang dianut seseorang. Dalam hal ini keabsahan suatu perkawinan dapat kita lihat pada Undang-undang yang sama pada pasal 2 ayat (1) yang menyatakan bahwa: "Perkawinan adalah sah apabila dilakukan menurut hukum masingmasing Agama dan kepercayaan itu." Selanjutnya pasal 2 ayat (2) dikatakan bahwa "tiap-tiap perkawinan dicatat menurut peraturan perundang-undangan yang berlaku." Sehingga resmi tercatat pada KUA dan mendapatkan surat

${ }^{1}$ Quzwini Perkawinan Siri dalam Perspektif Hukum Islam dan UU Nomor 1 Tahun 1974 tentang Perkawinan //kalsel.kemenag.go.id/file/file/Jurnal/csdq1384098941.pdf di akses 19 Mei 2017.

${ }^{2}$ Annisa Ridha Watikno. Akibat Hukum Perkawinan Siri terhadap Kedudukan anak Ditinjau dari Hukum Islam dan Undang-undang Perkawinan No 1 Tahun 1974 di Kabupaten Karanganyar (Jurnal Fakultas Hukum Universitas Surakarta, 2014).

Sangaji Jurnal Pemikiran Syariah dan Hukum 
nikah. ${ }^{3}$ Berdasarkan Fenomena yang terjadi dalam masyarakat bahwa nikah sirri, masih dilakukan oleh masyarakat tertentu. Disatu sisi, nikah sirri sah menurut hukum Islam asal memenuhi rukun dan syarat suatu pernikahan. Akan tetapi dalam Undang-undang Nomor 1 Tahun 1974 tidak sahnya suatu perkawinan tidak dicatat di Kantor Urusan Agama menurut peraturan perundang-undangan yang berlaku.

\section{Pemaknaan dan Hakikat Nikah Sirri}

\section{Pengertian Nikah Sirri}

Kata "Sirri" dari segi Etimologi berasal dari bahasa Arab, yang arti harfiyahnya, "Rahasia" (Secret Marriage). Menurut Terminologi figh Maliki, nikah sirri ialah : Nikah yang atas pesan suami, para saksi merahasiakannya untuk isterinya atau jama'ahnya, sekalipun keluarga setempat". Madzhab Maliki tidak membolehkan nikah sirri. Nikahnya dapat dibatalkan, dan kedua pelakunya bisa dikenakan hukuman had (dera atau rajam), jika telah terjadi hubungan seksual antara keduanya dan diakuinya atau dengan kesaksian empat orang saksi. Demikian juga Madzhab Syafi'i dan Hanafi tidak membolehkan nikah sirri. Menurut Madzhab Hambali, nikah yang telah dilangsungkan menurut ketentuan syari'at Islam adalah sah, meskipun dirahasiakan oleh kedua mempelai, wali dan para saksinya. Hanya saja hukumnya makruh. Menurut suatu riwayat, khalifah Umar bin al-Khatthab pernah mengancam pelaku nikah sirri dengan hukum had atau dera ${ }^{4}$

Istilah Sirri sebenarnya berarti sesuatu yang bersifat rahasia atau tertutup. Namun dalam perkembangan kemudian, dikalangan umum ada beberapa persepsi/asumsi yang memaknai perkawinan sirri sebagai berikut:

a. Perkawinan sirri adalah perkawinan yang dilangsungkan oleh seorang laki-laki dan seorang perempuan tanpa menggunakan wali atau saksi yang dibenarkan oleh syariat Islam. Menurut para ulama mereka sepakat bahwa perkawinan jelas ini adalah perkawinan yang

\footnotetext{
${ }^{3}$ Undang-Undang Republik Indonesia Nomor 1 Tahun 1974 Tentang Perkawinan //hukum. unsrat. ac.id/uu/uu_1_74.htm diakses 27 Mei 2017.

${ }^{4}$ Anggi Rosalia Nikah Siri dalam Islam-Pengertian-Hukum dan Jenisnyal/dalam islam.com / hukum-islam/ pernikahan/nikah-siri-dalam-islam di akses 20 Mei 2016.
} 
tidak sah dan bahkan disamakan dengan perzinahan sebagaimana hadits Nabi yang berbunyi "bahwa suatu pernikahan yang tidak menghadirkan empat pihak maka termasuk zina, empat pihak itu adalah suami, wali dan dua orang saksi yang adil".

b. Perkawinan sirri yakni perkawinan yang dilakukan oleh seorang laki-laki dengan seorang perempuan tanpa melibatkan petugas pencatatan perkawinan atau dapat juga dikatakan tidak dicatat oleh pencatat sebagaimana yang ditegaskan dalam ${ }^{5}$ Undang-Undang No. 1 Tahun 1974 tentang Perkawinan Pasal 2 ayat (2) Tiap-tiap perkawinan dicatat menurut peraturan perundang-undangan yang berlaku, Pasal 22 PP No. 9 Tahun 1975 tentang Peraturan Pelaksanaan Undang-Undang Perkawinan, Pasal 8 UU No. 23 Tahun 2006 tentang Administrasi Kependudukan. Dalam pengertian ini sebenarnya telah sesuai dengan syarat dan rukun perkawinan. Cuma saja perkawinan tersebut tidak dicatatkan oleh pegawai Pencatat Nikah (PPN) atau KUA.

\section{Tata Cara Perkawinan}

Pertama, dalam Undang-Undang No. 1 Tahun 1974, perkawinan merujuk Pasal 1 menyatakan bahwa perkawinan adalah ikatan lahir batin antara seorang pria dengan seorang wanita sebagai suami istri dengan tujuan membentuk keluarga (rumah tangga) yang bahagia dan kekal berdasarkan Ketuhanan Yang Maha Esa"; sedangkan mengenai syarat sahnya perkawinan pada pasal 2 Undang-undang Nomor 1 Tahun 1974 menyatakan bahwa: ayat (1) "Perkawinan adalah sah, apabila dilakukan menurut hukum masing-masing agamanya dan kepercayaannya itu". Sementara ayat (2) menyatakan, "Tiap-tiap perkawinan dicatat menurut peraturan perundang-undangan yang berlaku". 6 Selanjutnya menurut Peraturan Pemerintah No.9 Tahun 1975 tentang Pelaksanaan Undangundang Perkawinan pada Pasal 3 dikatakan:

a. Setiaporangyangakanmelangsungkan perkawinanmemberitahukan

${ }^{5}$ Undang-undang Republik Indonesia Nomor 1 Tahun 1974 tentang Perkawinan. //hukum.unsrat. ac.id/uu/uu_1_74.htm di akses 21 Mei 2016.

6 Lembaga Studi Advokat \& Masyarakat. Putusan Nomor 46/PUU-VIII/2010 Mahkamah Konstitusi Republik Indonesia, 2010, 8.

Sangaji Jurnal Pemikiran Syariah dan Hukum 
kehendaknya kepada Pegawai Pencatat Nikah di tempat perkawinan akan dilangsungkan.

b. Pemberitahuan tersebut dalam ayat (1) dilakukan sekurangkurangnya 10 hari kerja sebelum perkawinan dilangsungkan. Pengecualian terhadap jangka waktu tersebut dalam ayat (2) disebabkan sesuatu alasan yang penting, diberikan oleh Camat (atas nama) Bupati Kepala Daerah.

Dengan demikian pencatatan perkawinan walaupun diatur satu ayat di dalam Undang-Undang Perkawinan, namun masalah pencatatan ini sangat dominan. Akan tampak jelas menyangkut tata cara perkawinan itu sendiri yang kesemuanya berhubungan dengan pencatatan. Tidaklah berlebihan jika sementara ada pakar hukum yang menempatkannya sebagai syarat administratif yang juga menentukan sah tidaknya sebuah perkawinan. ${ }^{7}$

Kedua, menurut Kompilasi Hukum Islam (KHI) memuat masalah pencatatan perkawinan ini pada Pasal 5 yaitu $^{8}$ :

a. Agar terjamin ketertiban perkawinan bagi masyarakat Islam, setiap perkawinan harus dicatat.

b. Pencatatan perkawinan tersebut pada ayat (1) dilakukan oleh Pegawai Pencatat Nikah sebagaimana diatur dalam Undang-undang No. 22 Tahun 1946 jo. Undang-undang No. 32 Tahun 1954.

Selanjutnya pada Pasal 6 KHI dikatakan:

1) Untuk memenuhi ketentuan dalam Pasal 5, setiap perkawinan harus dilangsungkan dihadapan dan di bawah pengawasan Pegawai Pencatat Nikah.

2) Perkawinan yang dilakukan di luar pengawasan Pegawai Pencatat Nikah tidak mempunyai kekuatan hukum.

Selanjutnya, untuk melangsungkan perkawinan harus dilaksanakan menurut tata cara yang ditetapkan oleh peraturan perundang-undangan yang berlaku. ${ }^{9}$ Adapun tata cara pencatatan perkawinan adalah sebagai

${ }^{7}$ Nuruddin, Amiur dan Azhari Akmal Tarigan, Hukum Perdata Islam di Indonesia, (Jakarta: Prenada Media, 2004), 123.

${ }^{8}$ Disalin dari" Kompilasi Hukum Islam di Indonesia" (Direktorat Pembinaan Peradilan Agama Islam Ditjen Pembinaan Kelembagaan Islam Departemen Agama, 2001), 1.

${ }^{9}$ Quzwini Perkawinan Siri dalam Perspektif Hukum Islam dan UU Nomor 1 Tahun 1974 tentang Perkawinan //kalsel.kemenag.go.id/file/file/Jurnal/csdq1384098941.pdf di akses 19 Mei 2017. 
berikut:

a. Pemberitahuan kehendaknya kepada pegawai pencatat di tempat perkawinan akan dilangsungkan.

b. Penelitian, yang dilakukan Pegawai Pencatat Perkawinan.

c. Pelaksanaan perkawinan dilangsungkan setelah hari kesepuluh sejak pengumuman di atas dilakukan dan dilaksanakan menurut hukum masing-masing agama dan kepercayaannya, agar perkawinan itu sah. Sesaat setelah dilangsungkan perkawinan kedua mempelai menandatangani akta perkawinan yang telah disiapkan Pegawai Pencatat Perkawinan, begitu pula wali mempelai wanita, para saksi dan pegawai pencatat perkawinan yang menghadiri. Dengan selesainya penandatanganan akta perkawinan, maka perkawinan telah tercatat secara resmi.

\section{Tata Cara Pernikahan Sirri}

Kehidupan bersuami istri yang dibangun melalui lembaga perkawinan, sesungguhnya bukanlah semata-mata dalam rangka penyaluran hasrat biologis. Maksud dan tujuan nikah jauh lebih luas dibandingkan sekedar hubungan seksual. Bahkan apibila dipandang dari aspek religius, pada hakekatnya nikah adalah salah satu bentuk pengabdian kepada Allah. Karena itu, nikah yang sarat nilai dan bertujuan untuk mewujudkan kehidupan rumah tangga yang sakinah mawaddah wa rahmah, perlu diatur dengan syarat dan rukun tertentu agar tujuan disyariatkannya nikah tercapai. Rukun dan syarat menentukan suatu perbuatan hukum, terutama yang menyangkut dengan sah atau tidaknya perbuatan tersebut dari segi hukum. Kedua kata tersebut mengandung arti yang sama dalam hal keduanya merupakan sesuatu yang harus diadakan sahnya suatu pernikahan dalam Islam adalah dengan terlaksananya akad nikah yang memenuhi rukun dan syaratsyaratnya. ${ }^{10}$

Untuk sahnya perkawinan, para ulama telah merumuskan sekian banyak rukun dan syarat, yang mereka pahami dari ayat-ayat al-Qur'an maupun hadits Nabi SAW, diantaranya diharuskan adanya calon

${ }^{10}$ Amir Syarifuddin. Hukum Nikah Islam di Indonesia: Antara Fikih Munakahat dan UndangUndang Nikah (Cet. II; Jakarta: Kencana, 2007), 59.

Sangaji Jurnal Pemikiran Syariah dan Hukum 
suami isteri, wali, dua orang saksi, mahar serta terlaksananya ijab kabul merupakan rukun atau syarat sahnya suatu pernikahan. Adapun tata cara menikah sirri tidak jauh beda dengan menikah secara resmi di KUA, dimana dalam pernikahan itu harus dipenuhi syarat dan rukunnya.

a. Adanya calon suami dan istri yang akan melakukan perkawinan.

b. Adanya ijab qabul. Ijab artinya mengemukakan atau menyatakan suatu perkataan. qabul artinya menerima. Jadi Ijab qabul itu artinya seseorang menyatakan sesuatu kepada lawan bicaranya, kemudian lawan bicaranya menyatakan menerima. Dalam perkawinan yang dimaksud dengan "ijab qabul" adalah seorang wali atau wakil dari mempelai perempuan mengemukakan kepada calon suami anak perempuannya/ perempuan yang di bawah perwaliannya, untuk menikahkannya dengan lelaki yang mengambil perempuan tersebut sebagai isterinya. Lalu lelaki bersangkutan menyatakan menerima pernikahannya itu. ${ }^{11}$

c. Adanya Mahar (mas kawin)

Islam memuliakan wanita dengan mewajibkan laki-laki yang hendak menikahinya menyerahkan mahar (mas kawin). Islam tidak menetapkan batasan nilai tertentu dalam mas kawin ini, tetapi atas kesepakatan kedua belah pihak dan menurut kadar kemampuan. Islam juga lebih menyukai mas kawin yang mudah dan sederhana serta tidak berlebih-lebihan dalam memintanya. Dari Uqbah bin Amir, bersabda Rasulullah SAW : "Sebaik-baik mahar adalah yang paling ringan" (HR.Al-Hakim dan Ibnu Majah, shahih, lihat Shahih Al-Jamius Shaghir 3279 oleh Al-Albani)

d. Adanya Wali

Dari Abu Musa ra, Nabi SAW bersabda: "Tidaklah sah suatu pernikahan tanpa wali." (HR. Abu Daud dan dishahihkan oleh syaikh Al-Albani dalam Shahih Sunan Abi Dawud). Wali yang mendapat prioritas pertama di antara sekalian wali-wali yang ada adalah ayah dari pengantin wanita. Kalau tidak ada barulah kakeknya (ayahnya ayah), kemudian saudara lelaki seayah seibu atau seayah, kemudian

11 Fandi Israwan dan Novi Atika Sari. https:/ / fandyisrawan.wordpress. com/2014/02/26/makalah-nikah-siri/ diakses 10 Juni 2016 
anak saudara lelaki. Sesudah itu barulah kerabat-kerabat terdekat yang lainnya atau hakim.

e. Adanya Saksi-Saksi

Rasulullah SAW bersabda: "Tidak sah suatu pernikahan tanpa seorang wali dan dua orang saksi yang adil." (HR. Al-Baihaqi dari Imran dan dari Aisyah, shahih, lihat Shahih Al-Jamius Shaghir oleh Syaikh AlAlbani no. 7557). Menurut sunnah Rasulullah SAW, sebelum aqad nikah diadakan khuthbah lebih dahulu yang dinamakan khuthbatun nikah atau khuthbatul-hajat.

\section{Akibat Hukum Nikah Sirri}

\section{Secara Administrasi:}

Mengenai perkawinan sirri ini masih menjadi perdebatan yang cukup panjang. Menurut Pasal 4 Kompilasi Hukum Islam ("KHI"), Perkawinan adalah sah, apabila dilakukan menurut hukum Islam sesuai dengan Pasal 2 ayat (1) Undang-Undang No. 1 Tahun 1974 tentang Perkawinan ("UUP") yang menyebutkan "Perkawinan adalah sah apabila dilakukan menurut hukum masing-masing agama dan kepercayaannya itu." Namun, perkawinan tersebut harus dilaporkan dan dicatat di Kantor Urusan Agama atau di Catatan Sipil bagi yang bukan beragama Islam. Hal ini sesuai dengan ketentuan Pasal 2 ayat (2) Undang-Undang Perkawinan yang menyatakan "Tiap-tiap perkawinan dicatat menurut peraturan perundang-undangan yang berlaku". Begitu pula di dalam Pasal 5 KHI disebutkan:

1) Agar terjamin ketertiban perkawinan bagi masyarakat Islam setiap perkawinan harus dicatat.

2) Pencatatan perkawinan tersebut pada ayat (1), dilakukan oleh Pegawai Pencatat Nikah sebagaimana yang diatur dalam UndangUndang No. 22 Tahun 1946 jo Undang-Undang No. 32 Tahun 1954. ${ }^{12}$ Tanpa adanya pencatatan tersebut, maka anak yang lahir dari pernikahan sirri hanya memiliki hubungan hukum dengan ibunya atau keluarga ibunya.

12 "Kompilasi Hukum Islam di Indonesia", (Direktorat Pembinaan Peradilan Agama Islam Ditjen Pembinaan Kelembagaan Islam Departemen Agama, 2001), 1.

Sangaji Jurnal Pemikiran Syariah dan Hukum 
Berdasarkan menurut Komisi Perlindungan Anak Indonesia (KPAI), konstruksi sosial dari perbuatan perkawinan tidak dicatatkan dibedakan antara 3 (tiga) bentuk:

1) Perkawinan yang tidak dicatatkan (nikah sirri) yang bersifat eksploitatif berbentuk "kawin kontrak" yang dalam kasus tertentu terjadi antara warga negara asing dengan perempuan lokal.

2) Perkawinan yang tidak dicatatkan karena tidak memiliki akses terhadap pelayanan publik.

3) Perkawinan yang tidak dicatatkan yang bertujuan hanya sebagai pelampiasan hasrat seksual semata. ${ }^{13}$

Lebih lanjut, jika ditelaah secara mendalam Undang-undang Nomor 23 Tahun 2006 Tentang Administrasi Kependudukan, maka terdapat berbagai faktor yang menghambat anak memperoleh hak identitas atas akte kelahiran, yakni:

1) Asas "stelsel aktif bagi Penduduk".

2) Syarat-syarat formal pencatatan kelahiran (surat nikah/akta perkawinan, KK, KTP).

3) Pembatasan waktu 60 (enam puluh) hari melaporkan kelahiran menjadi hambatan dalam akses pencatatan kelahiran, jika melewatinya akan menjalani prosedur lebih panjang.

4) Pengenaan sanksi denda atas keterlambatan.

5) Tidak adanya fasilitasi dan bantuan Pemerintah.

6) Tidak adanya tindakan afirmatif untuk anak dari kawasan terisolir, anak berkesulitan khusus, anak tanda dokumen perjalanan (paspor) yang mengikuti orang tuanya bekerja di luar negeri.

7) Belum bebas biaya akte kelahiran.

\section{Kewarisan:}

Selain dampak dari administrasi yang bersifat negara, persoalan nikah sirri ini berkaitan erat juga dengan persoalan kewarisan antara anak dengan orang tua. Menurut pasal 42 Undang-undang Nomor 1 Tahun 1974 Tentang Perkawinan menyebutkan bahwa "Anak yang sah adalah anak yang dilahirkan dalam atau sebagai akibat perkawinan yang sah",

13 Komisi Perlindungan Anak Indonesia KPAI 2013. Perkawinan Tidak Dicatatkan: Dampaknya bagi Anak Ditayangkan oleh Tim KPAI 6,6, 2013, diakses 5 Desember 2016. 
dan Pasal 43 ayat (1) Undang-undang Nomor 1 Tahun 197 Tentang Perkawinan menyebutkan "Anak yang dilahirkan di luar perkawinan hanya mempunyai hubungan perdata dengan ibunya dan keluarga ibunya."Ini juga dikuatkan dengan ketentuan KHI mengenai waris yaitu Pasal 186 yang berbunyi:" Anak yang lahir di luar perkawinan hanya mempunyai hubungan saling mewaris dengan ibunya dan keluarga dari pihak ibunya."14 Oleh karena itu, dia hanya mewarisi dari ibunya saja. Jika berdasarkan Pasal 863 - Pasal 873 KUHPerdata, maka anak luar kawin yang berhak mendapatkan warisan dari ayahnya adalah anak luar kawin yang diakui oleh ayahnya (Pewaris) atau anak luar kawin yang disahkan pada waktu dilangsungkannya perkawinan antara kedua orang tuanya. Begitupun dalam kewarisan istri pernikahan sirri, ia tidak mendapatkan hak untuk mendapatkan bagian dalam pembagian waris.

\section{Nikah Sirri Dalam Tinjauan Hukum Islam dan Undang-Undang Perkawinan}

\section{Menurut Hukum Islam}

Hukum Islam merupakan rangkaian dari kata hukum dan kata Islam. Kedua kata itu secara terpisah, merupakan kata yang digunakan dalam bahasa Arab dan terdapat dalam al-Qur'an, juga berlaku dalam bahasa Indonesia. Hukum Islam sebagai suatu rangkaian kata telah menjadi bahasa Indonesia yang hidup dan terpakai dalam bahasa Arab dan tidak ditemukan dalam Al-Qur'an secara definitif. Secara Terminologi "Hukum Islam" dalam literatur berbahasa Arab biasanya menggunakan istilah figh dan Syariat atau hukum syara'. Syariat atau hukum syara' secara sederhana diartikan dengan seperangkat aturan dasar tentang tingkah laku manusia yang ditetapkan secara umum dan dinyatakan secara langsung oleh Allah dan Rasulnya. Figh secara sederhana diartikan sebagai hasil penalaran pakar hukum (Mujtahid) atas hukum syara yang dirumuskan dalam bentuk aturan terperinci.

Bila padanan kata hukum menurut definisi ini dihubungkan dengan Islam atau syara' maka makna hukum Islam akan berarti seperangkat

${ }^{14}$ Achmad Miftachul Alim 2015. Status anak dari pernikahan siri. Aliempolos.Blogspot. Com Materi Lengkap 27,01,2015, diakses 5 Desember 2016.

Sangaji Jurnal Pemikiran Syariah dan Hukum 
peraturan berdasarkan wahyu Allah dan sunah rasul tentang tingkah laku manusia mukallaf yang diakui dan diyakini mengikat untuk semua yang beragama Islam. ${ }^{15}$ Hasbi Asy-Shiddiqi memberikan definisi hukum Islam "Koleksi daya upaya para fuqaha dalam menerapkan Syariat Islam sesuai dengan kebutuhan masyarakat". Lanjutan, hukum Islam itu adalah hukum yang terus hidup, sesuai dengan Undang-undang gerak dan subur. Dia mempunyai gerak yang tetap dan perkembangan yang terus menerus. Karenanya hukum Islam senantiasa berkembang dan perkembangan itu merupakan tabiat hukum Islam yang terus hidup. ${ }^{16}$ Lebih lanjut Hukum Nikah sirri dengan pemahaman yang pertama, statusnya tidak sah, sebagaimana yang ditegaskan mayoritas Ulama. Karena diantara syarat sahnya nikah diharuskan adanya wali dari pihak wanita. Nikah tanpa wali maka dapat dikatakan tidak memenuhi syarat sahnya sebuah pernikahan, sebagaimana disebutkan dalam beberapa hadis diantaranya: Hadis dari Abu Musa Al-Asy'ari radhiallahu 'anhu, bahwa Nabi shallallahu 'alaihi wa sallam bersabda,

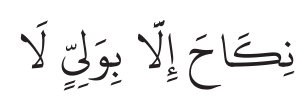

Artinya: "Tidak ada Nikah (batal), kecuali dengan Wali." (HR. Abu Daud, turmudzi, Ibn Majah, Ad-Darimi, Ibn Abi Syaibah, Thabrani,). ${ }^{17}$

Selain itu terdapat pula hadis dari Aisyah radhiallahu 'anha, bahwa nabi shallallahu 'alaihi wa sallam bersabda:

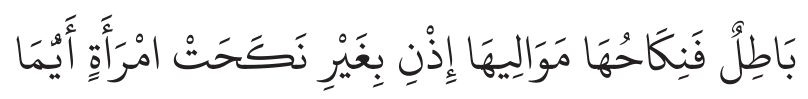

Artinya: "Wanita manapun yang menikah tanpa izin wali, maka nikahnya batal." (HR yang lima kecuali Imam An Nasaaiy. Lihat, Imam Asy Syaukaniy, Nailul Authar VI: 230 hadits ke 2649).

Jika yang dimaksud nikah sirri adalah nikah di bawah tangan, dalam arti tidak dilaporkan dan dicatat di lembaga resmi yang mengatur pernikahan, yaitu KUA maka status hukumnya sah, selama memenuhi

${ }^{15}$ Muhammad Mutawali. Islam di Bima Implementasi Hukum Islam oleh badan Hukum Syara Kesultanan Bima 1947-1960 (Alam Tara Institute Mataram Kerjasama dengan IT-Pres STIS AlIttihat Bima, 2013), 27-28.

${ }^{16}$ Hasbi Asy-Shiddiqi. Falsafah Hukum Islam. (Jakarta: Bulan Bintang, 1993), 44

${ }^{17}$ Muhammad Ibnu Rusy.Bidayatul Mujtahid Darul Fikri. (Bairut Libanon. Juz 2), 9. 
syarat dan rukun nikah. Sehingga nikah sirri dengan pemahaman ini tetap mempersyaratkan adanya wali yang sah, saksi, ijab-qabul akad nikah. Hanya saja, pernikahan semacam ini sangat tidak dianjurkan, karena beberapa alasan: Pertama, pemerintah telah menetapkan aturan agar semua bentuk pernikahan dicatat oleh lembaga resmi yakni KUA. Sementara kita sebagai kaum muslimin, diperintahkan oleh Allah untuk menaati pemerintah selama aturan itu tidak bertentangan dengan syariat. Allah berfirman:

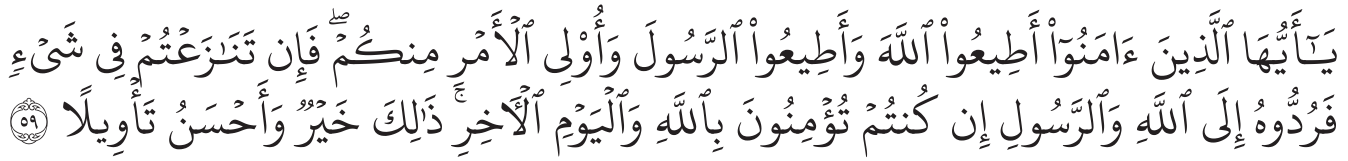

Artinya:

Hai orang-orang yang beriman, taatilah Allah dan taatilah Rasul (Nya), dan ulil amri di antara kamu. kemudian jika kamu berlainan Pendapat tentang sesuatu, Maka kembalikanlah ia kepada Allah (Al-Qur'an) dan Rasul (sunnahnya), jika kamu benar-benar beriman kepada Allah dan hari kemudian. yang demikian itu lebih utama (bagimu) dan lebih baik akibatnya. (QS. An-Nisa: 59). ${ }^{18}$

Kedua, adanya pencatatan di KUA akan semakin mengikat kuat kedua belah pihak. Dalam Al-Quran, Allah menyebut akad nikah dengan perjanjian yang kuat (مِيًَاقًا غَلِيظًا), sebagaimana yang Allah tegaskan di surat An-Nisa.

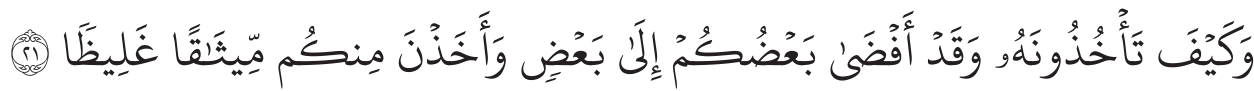

Artinya:

Bagaimana kamu akan mengambilnya kembali, Padahal sebagian kamu telah bergaul (bercampur) dengan yang lain sebagai suami-isteri. dan mereka (isteri-isterimu) telah mengambil dari kamu Perjanjian yang kuat (QS. An-Nisa: 21)

\section{Menurut Undang-Undang Nomor 1 Tahun 1974 Tentang Perkawinan}

Selama ini, masalah perkawinan di Indonesia diatur dalam UndangUndang Nomor 1 Tahun 1974 tentang Perkawinan. Keberadaan Undang-

${ }^{18}$ Departemen Agama RI, Al-qur'anulkarim, 87

Sangaji Jurnal Pemikiran Syariah dan Hukum 
Undang Perkawinan di Indonesia dimaksudkan untuk menampung keanekaragaman peraturan perkawinan dan memberikan landasan hukum perkawinan yang dapat dijadikan pegangan dan berlaku bagi semua golongan masyarakat yang berada di Indonesia. Perkawinan menurut Pasal 1 Undang-Undang Nomor 1 Tahun 1974 tentang Perkawinan adalah: "Ikatan lahir batin antara seorang pria dengan seorang wanita sebagai suami isteri dengan tujuan membentuk keluarga (rumah tangga) yang bahagia dan kekal berdasarkan Ketuhanan Yang Maha Esa". ${ }^{19}$ Adapun untuk melangsungkan perkawinan yang sah, harus dipenuhi syaratsyarat perkawinan sebagaimana diatur dalam Pasal 6 sampai dengan Pasal 12 Undang-Undang Nomor 1 Tahun 1974 tentang Perkawinan. Sedangkan perkawinan dalam pengertian hukum Islam adalah pernikahan, yaitu akad yang sangat kuat atau mitsaqan ghaliidzan, untuk mentaati perintah Allah dan melaksanakannya merupakan ibadah. ${ }^{20}$

Dengan tidak diakuinya perkawinan sirri dalam Undang-Undang Nomor 1 Tahun 1974, maka perkawinan sirri dianggap tidak sah menurut Undang-Undang. Kondisi demikian tentunya menimbulkan permasalahan-permasalahan, khususnya mengenai kedudukan hukum anak yang dihasilkan dari perkawinan sirri. Mengenai anak yang lahir dari perkawinan sirri ini masih menjadi perdebatan yang cukup panjang. Menurut Kompilasi Hukum Islam ("KHI") Pasal 4, bahwa Perkawinan adalah sah, apabila dilakukan menurut hukum Islam sesuai dengan Pasal 2 ayat (1) Undang-Undang No. 1 Tahun 1974 tentang Perkawinan. ("Undang-Undang Perkawinan") yang menyebutkan "Perkawinan adalah sah apabila dilakukan menurut hukum masing-masing agama dan kepercayaannya itu. ${ }^{21}$ Namun, perkawinan tersebut harus dilaporkan dan dicatat di Kantor Urusan Agama atau di Catatan Sipil bagi yang bukan beragama Islam. Hal ini sesuai dengan ketentuan Pasal 2 ayat (2) Undang-Undang Perkawinan yang menyatakan “Tiap-tiap perkawinan

${ }^{19}$ Direktorat Pembinaan Peradilan Agama, Himpunan peraturan perundang-undangan dalam lingkungan peradilan agama (Jakarta: Yayasan al-Hikmah, 2003), 131.

${ }^{20}$ Achmad Miftachul Alim/ alimpolos. Blogspot. co.id/ 2015/ 01/status-anak-dari-pernikahansiri.html diakses 10 Juni 2016.

${ }^{21}$ Lihat Pasal 5 Kompilasi Hukum Islam ("KHI"), di Sebutkan 1. Agar terjamin ketertiban perkawinan bagi masyarakat Islam setiap perkawinan harus dicatat. 2. Pencatatan perkawinan tersebut apada ayat (1), dilakukan oleh Pegawai Pencatat Nikah sebagaimana yang diatur dalam (Undang-undang No.22 Tahun 1946 jo Undang-undang No. 32 Tahun 1954), 1. 
dicatat menurut peraturan perundang-undangan yang berlaku. Tanpa adanya pencatatan tersebut, maka anak yang lahir dari pernikahan sirri hanya memiliki hubungan hukum dengan ibunya atau keluarga ibunya".

Maka, pernikahan harus tercatat secara jelas agar tidak terjadi berbagai konflik dan dampak dalam masyarakat itu sendiri, terlebih pernikahan yang tidak tercatat dianggap cacat hukum yang berakibat pernikahan tersebut tidak diakui sebagaimana pernikahan sirri yang terjadi. Akibatnya, baik itu

\section{Penutup}

Berdasarkan uraian yang telah penulis paparkan di atas, maka dapat disimpulkan bahwa,

Pertama, dalam konsep Islam pernikahan sirri sangat tidak dianjurkan, dan juga kebijakan untuk mencatatkan pernikahan itu pada prinsipnya sangat dianjurkan karena kaum Muslimin diperintahkan oleh Allah untuk menaati pemerintah selama aturan itu tidak bertentangan dengan syariat dalam QS An-Nisa ayat 59, selain itu dengan adanya pencatatan akan menguatkan pernikahan tersebut sebagaimana dalam QS. An-Nisa ayat 21. Nikah Sirri yang diperbolehkan dalam hukum Islam adalah nikah yang syarat dan rukun nikahnya telah terpenuhi yaitu: wali nikah, dua orang saksi yang adil, ijab dan kabul. Sementara nikah sirri yang dilakukan tampak adanya wali nikah adalah tidak sah

Kedua, dalam konteks perundang-undangan, nikah haruslah dicatatkan. Akan tetapi karena tidak dilakukan pencatatan, secara formal yuridis perkawinan tersebut tidak memenuhi syarat sebagaimana ketentuan yang diatur oleh Undang-undang Perkawinan (UU No.1 Tahun 1974) dan peraturan pelaksanaannya. Nikah sirri sah menurut hukum Islam, namun apabila tidak dicatatkan di Kantor Urusan Agama hukumnya tidak sah, menurut Undang- undang perkawinan Pasal 2 ayat 2 perkawinan tersebut tidak memiliki legal hukum. Artinya segala hak yang timbul yang dilindungi oleh undang-undang tidak diberikan seperti pengakuan oleh hukum atas anak yang dilahirkan sehingga pemerintah tidak dapat melindungi hak-hak anak tersebut seperti memberikan akta kelahiran. Pencatatan perkawinan itu penting untuk kepastian hukum anak yang dilahirkan dan menghindari akibat hukum yang timbul dari 
perkawinan tersebut, baik dalam hubungan antara suami istri tersebut, juga dalam hubungannya dengan pihak ke tiga, misalnya tentang sahnya anak, kewarisan, dan sebagainya.

\section{Daftar Pustaka}

Asy-Shiddiqi, Hasbi. Falsafah Hukum Islam. Jakarta: Bulan Bintang, 1993. Aulawi, Wasit. Pernikahan Harus Melibatkan Masyarakat, Mimbar Hukum, No. 28, 1996.

Departemen Agama RI. Al-qur'anulkarim.

Direktorat Pembinaan Peradilan Agama. Himpunan peraturan perundangundangan dalam Lingkungan Peradilan Agama. Jakarta: Yayasan alHikmah, 2003.

Hawari, Dadang, Nikah Siri Tidak Barakah, http://malangraya.web.id.

Israwan, Fandi. dan Novi Atika Sari. https://fandyisrawan.wordpress. com/2014/02/26/makalah-nikah-siri/ diakses 10 Juni 2016

Kitab Undang-Undang Hukum Perdata (Burgerlijk Wetboek voor Indonesie) Staatsblad Tahun 1847 Nomor 23 Diumumkan Dengan Maklumat, Tanggal 30 April 1847.

Kompilasi Hukum Islam di Indonesia", Direktorat Pembinaan Peradilan Agama Islam Ditjen Pembinaan Kelembagaan Islam Departemen Agama, 2001.

Lembaga Studi Advokat \& Masyarakat. Putusan Nomor 46/PUU-VIII/2010 Mahkamah Konstitusi Republik Indonesia, 2010.

Lihat Menurut Pasal 5 Kompilasi Hukum Islam ("KHI”), di Sebutkan 1. Agar terjamin ketertiban perkawinan bagi masyarakat Islam setiap perkawinan harus dicatat. 2. Pencatatan perkawinan tersebut apada ayat (1), dilakukan oleh Pegawai Pencatat Nikah sebagaimana yang diaturdalam Undang-undang No.22 Tahun 1946 jo Undang-undang No. 32 Tahun 1954.

Muhammad Ibnu Rusy-Bidayatul Mujtahid . Darul Fikri. Bairut Libanon. Juz 2.

Mutawali, Muhammad. Islam di Bima Implementasi Hukum Islam oleh Badan Hukum Syara Kesultanan Bima (1947-1960) Penerbit Alam Tara Institute Mataram Kerjasama dengan IT-Pres STIS Al-Ittihat Bima, 2013. 
Nikah Siri dalam Islam-Pengertian-Hukum dan Jenisnya//dalam islam. com /hukum-islam/ pernikahan/nikah-siri-dalam-islam.

Nuruddin, Amiur dan Azhari Akmal Tarigan. Hukum Perdata Islam di Indonesia. Prenada Media, Jakarta, 2004.

Shihab, Quraish, Wawasan al-Qur'an: Tafsir Maudhu'i Atas Perbagai Persoalan Umat. Cet. VIII; Jakarta: Mizan, 1998.

Syarifuddin, Amir. Hukum Nikah Islam di Indonesia: Antara Fikih Munakahat dan Undang-Undang Nikah.Cet. II; Jakarta: Kencana, 2007.

Undang-undang Republik Indonesia nomor 1 tahun 1974 tentang perkawinan. //hukum.unsrat.ac.id/uu/uu. 